\title{
One Belt One Road-New Game, Established Rules
}

\author{
Weimin Wang, Shitao Huo \\ School of Government, Shanghai University of Political Science and Law, Shanghai, China \\ Email: wangweimin@shupl.edu.cn, huobst@yahoo.com
}

How to cite this paper: Wang, W. M., \& Huo, S. T. (2019). One Belt One Road-New Game, Established Rules. Open Journal of Political Science, 9, 582-597.

https://doi.org/10.4236/ojps.2019.93035

Received: June 23, 2019

Accepted: July 28, 2019

Published: July 31, 2019

Copyright $\odot 2019$ by author(s) and Scientific Research Publishing Inc. This work is licensed under the Creative Commons Attribution International License (CC BY 4.0).

http://creativecommons.org/licenses/by/4.0/

\begin{abstract}
Some, both in and outside of academia, have serious concerns that the One Belt One Road (OBOR) initiative at such an unprecedented scale would inadvertently destabilize current patterns of international rules (Authors' notes). However, our tracking data has clearly shown that the OBOR initiative has not intended to reach, nor has actually performed, beyond the existing framework of international order. One of the unexpected discoveries we made as we determined what rules dictated the OBOR progress was that established rules since the Bretton Woods System and the UN appeared to function properly when relevant parties worked for their deals. The research was designed to investigate the operational rules in OBOR's economic activities. Its methodology is associated with the role of free markets in international relations, but we examined the governance established by the international regimes. We also established analytical structure to explore the effects of variables such as reciprocity, nondiscrimination, and sovereignty. Our findings were convincing to say the least, the established international order and rules, norms, and decision making procedures inspired all actors in the OBOR initiative. Even compromised policies beyond current rules would normally be considered as being tentative solutions. We trust that our readers will find our tracking data based empirical method as effective and they will benefit from our analysis and discoveries as they observe and involve themselves in the OBOR processes.
\end{abstract}

\section{Keywords}

International Regimes, Rules, Norms, Globalization, Governance, Global Wealth Distribution, Policy Space

\section{Introduction}

When China announced its One Belt One Road (OBOR) initiative, no one could 
have envisaged the extensive resonance from countries of all global regions. Some view it as a new game since the Marshall Plan, considering its similar objectives of revitalizing the world markets, yet with much aggressive scales, and economic and financial resources crossing vast areas of lands and oceans. Since the OBOR Global Forum in 2017, 132 countries have participated or demonstrated their enthusiasm with the initiative; 64 countries have become members of the financial institution of OBOR-Asian Infrastructure and Investment Bank (AIIB). The entire international community has been deeply intrigued and excited about the positive opportunities this new game will be offering. Infrastructure investment of approximately $\$ 4$ - 8 trillion will connect China with the rest of Asia, Europe and Africa. The initiative will cover $65 \%$ of the world population in more than 68 countries, and will contribute over $40 \%$ of the global GDP. It will also make $30 \%$ plus world's total trade across the belt and road regions per year. Additionally, the investments in infrastructure will create spillover effects to innumerable sections for socioeconomic development for many years to come.

On the other hand, some have serious concerns that the OBOR at such an unprecedented scale would inadvertently destabilize current patterns of international rules. However, our tracking data has clearly shown that the initiative has not intended to reach, nor has actually performed, beyond the existing framework of international order. The established rules since the creation of world organizations still remain the cornerstone for layers of regulations and management in the relations among states. Primarily, we are still living in a community dictated by the same international regimes. The legitimacy of international organizations has been well established by the general recognition of all member nations. As a result, members of the international society most regularly choose to respect and comply with laws, rules, norms and decision making procedures of their common society. Despite the theoretical debate on certain issues, the traditional rules, have by and large, served the fundamental guidelines for the international security and stability. Critical rules including reciprocity, non-discrimination, and self-determination are still being strictly adhered to by all the parties when it comes to their economic interactions. Any complementary remedies to the current rules will all have to hinge on rationality and recalibration of the needs due to their exquisite relations.

\section{Theories and International Regimes of Liberal Economics}

Pioneers of the international community have long envisioned the ideal paradigm for world peace under a set of dominating rules. Despite human's natural partiality and flawed world politics, nothing could stop their duties to seek for peaceful relations among nations (Heymann, 1973). To many, domestic representative government and commercial capitalism highlight the pacifying nature of an international system as war does not benefit commercially manufacturing societies, and the commerce would extirpate the system of war (Schumpeter, 1955; Paine, 1791). Brilliant proposal for perpetual peace based on republican 
government, non-discrimination, and interdependence foresaw the benefits and interest, and projected possible framework of rules for games of all nations (Kant, 1795).

Generations later, after devastating lessons learned, men finally demonstrated their wisdom through general consensus on their common mode of behavior for a world system. International governmental organizations and international economic systems have all taken initiatives to create rules dictating international relations, and thereupon, succeeded in assisting people of all nations to approach peace, stability and prosperity. Among all others, the rules of reciprocity, non-discrimination, and sovereignty are fundamental and are being respected and complied by all the members of international society.

The One Belt One Road, one of the latest and largest planed initiatives, has been following the identical rules in various venues without exceptions. In its recent roundtable forum consisting of leaders of 132 countries and 70 international organizations, a joint communiqué was signed by all the participants to promise to honor the principles of the UN Charter and international law. These include seeking reciprocal benefits; adhering to non-discrimination and concerning the perspectives of all stakeholders; respecting the sovereignty and territorial integrity of countries (Yamei, 2017), as well as a great number of other guidelines for economic convergence and prosperity. OBOR's well received missions and goals parallel with the UN's principles, rules and norms, and won indispensable legal endorsement and moral support from international organizations. UN Resolutions S/2274 and A/71/9 of 2016, passed by unanimous vote, acknowledged the contents of the OBOR initiative and called upon all countries along the Belt and Road for cooperation (People's Daily, 2017).

\section{Reciprocity}

Originating from GATT (General Agreement of Tariffs and Trade) and carried over by WTO, the rule of reciprocity (Marchetti, Roy, \& Zoratto, 2012) addresses mutually beneficial relations for economic transactions. Such relations refer to the granting of mutual concessions in tariff rates, quotas, or other commercial restrictions. The logical extension of reciprocity could include all activities involving concessions made by bilateral and multilateral parties in all of their economic transactions. Remarkable progresses have been witnessed for reciprocal relation in great spectrum of areas since the launch of the initiative along the belt and road, including trade growth, investment, jobs, revenue incomes, GDP growth.

\subsection{Trade}

Statistics show that China's total trade volume with countries along the Belt and Road surpassed 3.0 trillion US dollars from 2014 to 2016. Table 1 suggests that total trade volume steadily increased in most years since 2011 (Qiu \& Zhao, 2017). Malaysia and Thailand are among twelve other countries having trade surplus with China. 
Table 1. China and the OBOR countries trade total_2011-2016 (USD Billion).

\begin{tabular}{ccccccc}
\hline Year & 2011 & 2012 & 2013 & 2014 & 2015 & 2016 \\
\hline Trade Total & 894.11 & 959.84 & 1040.5 & 1120.4 & 1002.92 & 953.59 \\
\hline
\end{tabular}

Source: People's Daily, Statistics Proof of One Belt \& One Road Achievements in Trading, (August 24, 2017).

\subsection{Investment}

FDI has been spearheading the boom of aggressive infrastructure campaign since 2013 in vast areas across the continents. This has proved to be the first step towards infinite possibilities as investments displayed its magic in the economic renaissance of West European states, and a rising China.

Large-scale investments for incredibly difficult projects over some geographic roadblocks can be considered a gift to the developing nations along the belt and road. As shown in Table 2, the center of gravity in capital investment has been exclusively flowing to the infrastructure related projects. Obviously, such definitive and bold decisions have been made under significant pressure and risk due to concerns of short and medium term revenue returns. However, one can also discover the medium to long term benefits that these projects may generate due to their crucial and foundational impact. Between the initial year of 2013 and three years moving forward, OBOR has managed to build a total number of three gas/oil pipelines, seven power stations, one overseas bridge, three sea ports, one regular tunnel plus one another cross two-ocean tunnel, and fourteen regular or high speed railways.

Other major logistic construction projects include SEZ (Special Economic Zones), telecom, refineries, highest-voltage transmission line, silk road banks, steel producers, industrial park, nuclear power station, remote sensing satellite, emergency command and control center, submarine optical cable and cross-border land optical cable, China-Europe freight trains, and at least eight MOUs (Memorandum of Understanding) signed between China and Central-Eastern European states.

The OBOR investment projects are positive for developing countries, and provide an opportunity to developing countries to improve their physical infrastructure stock. China's investment in Africa, around $\$ 670$ billion since 2009, best exemplifies the infrastructure push and pull strategy for economic development and noticeable changes that result. In the long run, the initiative will also enhance the competitiveness of the private sector in many countries, creating positive spill-over effects extending far beyond the initial projects, facilitating further investment.

\subsection{Jobs}

One immediate payoff by these tenacious investment efforts is the jobs that it helps create for the host countries. By October of 2017, OBOR initiative projects have created over 160,000 jobs along belt and roads countries, while the global 
Table 2. List of Investment in the One Belt One Road Initiative: 2013-2016.

\begin{tabular}{|c|c|c|c|c|c|c|c|}
\hline Areas & $\begin{array}{l}\text { Gas/Oil } \\
\text { Pipeline }\end{array}$ & $\begin{array}{l}\text { Power } \\
\text { Stations }\end{array}$ & Railway & Bridges & Ports & Tunnels & $\begin{array}{l}\text { Refinery/Telecom/ } \\
\text { Logistics/Bank/SEZ/ } \\
\text { Steel Prod/MOU }\end{array}$ \\
\hline Central Asia & 1 & 1 & 1 & & & 1 & 1 \\
\hline Southeast Asia & 2 & 3 & 3 & & & & 2 \\
\hline South Asia & & 1 & & 1 & 2 & & 2 \\
\hline Africa & & & 4 & & & & 1 \\
\hline Europe & & 1 & 4 & & 1 & & $2+8(\mathrm{MOU})$ \\
\hline Latin America & & 1 & 2 & & & 1 & 2 \\
\hline China & & & & & & & 5 \\
\hline Total & 3 & 7 & 14 & 1 & 3 & 2 & $15+8(\mathrm{MOU})$ \\
\hline
\end{tabular}

Source: People Net, 1997-2016 by www.people.com.cn; http://en.people.cn/102775/313196/index.html (Beijing).

unemployment rate remains of 2.2 million a year in the past five consecutive years (Chinanews, 2017). It is estimated that the average employment growth rate by OBOR countries have been $0.093 \%$ higher than other non OBOR countries. The highest impacted labor market is the male employment at $0.138 \%$ and higher education employment at $1.276 \%$ (Lu, 2017).

Global businesses have also found themselves sharing benefits by the influx job creation. General Electric, the US conglomerate, expects to receive orders exceeding \$2 billion from Chinese engineering, procurement and construction companies in 2016. John Rice, GE's vice chairman, has called the Belt and Road Initiative "a multi-win strategy." Honeywell, another US conglomerate, has 23 branches and more than 32,000 local staff in Silk Road countries. It is estimated that the public-private partnerships clustered around infrastructure have the potential to increase global growth and create millions of jobs in the most demographically challenged countries (Kanak, 2016).

Continued data shows that OBOR job creation helps ameliorate the political tensions arising from the last international financial crisis. Greece, which had been chastised by EU for its eurozone's delinquency, had embraced China's cash investment, and all the fortunes generated. After billions of Chinese dollars have been spent for upgrading its seaports, airports, ship manufactures and transportation, tens of thousands of jobs have been created. Additionally, hundreds of thousands of Chinese travellors contributed to huge revenue incomes for the state. Much of the political tensions between previously unemployed labors and their employers and the states have been eased as result (Atzori, 2016).

\subsection{Revenues}

By mid 2017, the OBOR initiative has been established in 56 economic collaborative regions, generating about 1.1 billion tax revenues, and contributes to 180 thousand jobs for the countries along the belt and roads (Zhao \& Luo, 2017). 
Private western companies have managed to make remarkable volume of revenues in participating in the initiative projects. Honeywell's China sales reached $6 \%$ or $\$ 2.4$ billion of its revenue in 2016 alone; Siemens reported revenue of $€ 3.25$ billion in China ( $\$ 3.55$ billion) in the first half of its 2017's fiscal year; ITT is involved in several OBOR related projects, and its Asian Pacific accounted for $12 \%$ of ITT's global revenue in 2016. Caterpillar has established huge growth due in part to the initiative, and continues to maintain its stronger quality and technology versus its Chinese competitors. Their sales in the last quarter of 2017 alone increased over 20\%, compared to the previous year (Trentmann, 2017; The Sirius Report, 2018).

\subsection{GDP Growth}

It is estimated that OBOR will bring $40 \%$ of GDP growth for the countries along the belt and road (Wang, 2017). Applying the GTAP model with comparative static simulations, one study confirms the substantial OBOR impact within Asian countries. First of all, infrastructure renovation will enormously enhance the area's transportation and facilitate trade. This alone will stimulate the GDP growth in Central, West and South Asia by 0.1 to 0.7 percent. Secondly, it will also increase the welfare for the countries from $\$ 6$ billion to $\$ 100$ billion. Thirdly, this will drive export volumes from $\$ 5$ billion to an astounding $\$ 135$ billion level (Villafuerte, Corong, \& Zhuang, 2016).

\section{Non-Discrimination}

The second grand rule of WTO is Non-Discrimination. The rule started out from MNF (Most Favored Nations) of GATT, which governs trading and other economic transactions under the comprehension of treating other people equally (World Trade Organization). The rule specifies four principles that define such equal relations: free trade through negotiation, predictability through binding and transparancy, promoting fair competition, and encourage development and economic reform.

\subsection{Free Trade Agreement}

Countries along the belt and road have been actively participating in free trade agreements over the past several years. They have worked out significant and wide range deals with the likes of ASEAN, Australia, Singapore, South Korea, New Zealand, Hong Kong and Macau, Pakistan, Gulf Countries, Sri Lanka, Georgia, Eurasian Economic Union and such (Dezan Shira \& Associates, 2017).

One of the essential features of these agreements is for free trade through rounds of negotiations. Take ASEAN-China free trade agreement as an example. It was primarily signed and put in force by seven ASEAN members back in 2010, and extended to include three more countries who requested time for considering and adjustment. The latest version of agreements among members aims to eliminate tariffs on $95 \%$ of all trading goods and services. Agreements of similar nature have also helped Hong Kong and Macau to access special restricted in- 
vestment areas in Mainland China, and with preferential tax reduction plans (Dezan Shira \& Associates, 2017).

\subsection{Transparency}

Many have concerns about the China-led initiative and its state sponsored financial power in the project bidding processes. However, many private owned enterprises have also found equal footing in winning contract opportunities with their real competitive capacities. Since day one of the OBOR initiative, GE has been successfully beating out many private and public competitors from China, earning itself $\$ 2.3$ billion of contract orders, and is now pushing for an additional $\$ 7$ billion in orders for natural-gas turbines and heavy power equipment. In the same vein, Citibank-one of world's largest financing power houses, won a contract bidding from the Bank of China in 2016. This allows the company to manage bonds estimated at $\$ 3$ billion to raise money for its extensions all over Asian, Eastern Europe and East Africa. Another US technology and manufacturing company Honeywell has been allowed to sell its equipment to Central Asia for processing natural gas (Bradsher, 2017).

Other foreign firms are expecting positive collaboration with OBOR projects with their unique potentials and instant impact. DP World declared they have ports alongside the OBOR routes and are ready to expand those at any moment; DHL, a German based freight forwarder, is actively promoting for new international transportation routes which span across Eurasia, China-Europe rail lines; HP, an American firm which helps facilitate the China-Europe direct cargo trains, is expecting extended cooperation with initiative; and GE, who currently operates $34 \%$ of joint venture in China generating $\$ 8$ billion each year for the company, is shooting for their third-party country sales from $\$ 1$ billion to $\$ 10$ billion per year (Shepard, 2017). Other big name companies that have or will be involved in the OBOR initiative include Siemens, Swiss-Swedish multinational ABB, Italian Argentine Techint Group, BHP Billiton and Rio Tinto, Shell, Nike, Apple, Coca-Cola, Nestle, and etc. (Cendrowski, 2016).

It has found projects along the OBOR routes, multiple zones of competition are existing among ADB (Asian Development Bank), MDB (multilateral development bank), and Eastern Central European funders, in addition to AIIB. Table 3 indicates many exsiting projects funded by multilateral development banks for the contractors participating in projects. Of them, 29 percent are Chinese, 40.8 percent are local, and 30.2 percent are foreign. Having such a record is a strong testimony for the improving of transparency levels in the overall initiative, especially when considering the extreme competitiveness of Chinese transportation

Table 3. Percentage of multiple zones of funders in the OBOR projects.

\begin{tabular}{cccc}
\hline Zones & China & Local & Foreign \\
\hline Percentage $\%$ & $29 \%$ & $40.8 \%$ & $30.2 \%$ \\
\hline
\end{tabular}

Source: Hillman (2018). China's Belt and Road Initiative: Five Years Later, CSIS (Center for Strategic and International Studies) Report. 
sectors. Both western and local firms will continue to find success in OBOR investment with their advantages in technologies, as well as their consultation and legal services.

Addressing concerns over transparency of sensitive environmental issues, many positive actions have been observed from recent Chinese sponsored events and policy announcements. When the US stepped out of leadership responsibility on climate management, China in the 2016 Hangzhou G20 summit championed green finance and showed its commitment to the largest issue of green bonds in 2016. The AIIB declares definitively that its USD $\$ 100$ billion's investment along the routes will be dedicated to the countries under the guidelines of "lean, clean, and green" and their commitment to Paris Agreement. AIIB has pledged an extremely rigid policy over the funding of fossil fuel plants, and has yet to approve of any such proposals. On the other hand, much of its efforts have focused on pursuing green investment opportunities from solar, thermal, and hydropower projects in Pakistan, Vietnam, Ecuador and to extensive rail networks in everywhere else (Pike, 2017).

\subsection{Fair Trade}

China has been negotiating trade agreements with all possible participants along the belt and road. Two driving features of such trade talks are epitomized by respect of trading partners' needs, and exploring alternatives for better trading conditions. China and Georgia are working actively on their trading negotiations with eyes on unique commodities for exchange. Chinese buyers have already been to Tbilisi looking for high quality products like wine and fruits from Georgia. As for purchasing prices, China has offered Georgia significantly reduced prices for their produces. Similar data source has also discovered that China-Gulf Co-Operation Council countries have reached agreement for China to trade for energy products, as well as for Gulf countries to benefit from affluent Chinese tourists to the region and services the host countries provide. A similar deal between China-Sri-Lanka has reached the same objective to include tourism for the beautiful naval sceneries along Sri-Lanka's seaside (Pike, 2017).

\subsection{Grow Together through Reform}

OBOR's challenges are sustainability and renovation on investment structure it requires. Today's world has reached a green consensus for a clean environment across the global community. The traditional strategies of a great number of industrial sectors are increasingly constrained by the changing mentality for better quality of life. It is either they go against mainstream needs, or they survive with a reformed mind. President Xi attended 2015 UN Sustainable Development Summit, and made sure that China's long term strategy along the "Paris Agreement" should not be derailed; with an already huge amount invested into renewable energy, China has committed additional $\$ 361$ billion to clean energy over coal-fired power plants by 2020; China has also launched a campaign for "ecological civilization" since 2012, searching for solutions to protect its citizens 
and economy from climate change and air pollution. It has since become much clearer that clean investment has been well received and welcomed by the majority of local people in the countries alongside the routes. African countries in particular share their deep interests and vision for their full economic potential and electricity-access goals through clean energy and sustainable development (Camdessus, 2017).

\section{Sovereignty}

Sovereignty is a conceptual rule of international society since the Peace of Westphalia, and a practical rule dictating inter-states relations since the creation of the United Nations. All things considered, this rule encompasses all tangible and intangible authorities of a government over its territory, government, legal system, and people above any other powers or interference from external environment. The OBOR initiative makes sure it takes national sovereignty seriously, and encourages voluntary participation, respect of legal system, and contracts with no political, economic and military strings attached.

\subsection{Voluntary Participation}

Facing the regionalized trend in economic cooperation, China's OBOR initiative presents the world an alternative approach to globalization. In many occasions, China has reiterated that this opportunity is open and voluntary to all countries and international organization. With overall economic power, strong infrastructure and construction technology, robotic financial sources, and commitment to "lean, clean and green", it is really hard to refuse the amazing opportunities when the initiative calls upon the active participation with whatever intentions. And this is true especially when considering the fact the majority of the participating countries are in fact those who were hard hit by the last internal financial crisis, or badly in need of opportunity for continuing development, most of which are countries tied by terrains or marine connectivity spreading over the vast areas in Asia, Africa, and Latin America (Wu, 2017). Therefore, the real voluntary campaign goes swiftly beyond its originally intended scopes, making it a club of hundred members. OBOR turns out a synonym for an all-inclusive globalizing aspiration.

\subsection{Respect of Legal System}

One of the challenging issues to the OBOR initiative is the discrepancy among various legal systems applied by countries along the routes. History, culture, and tradition originating from these systems constitute institutional approach to the reconciliation or barriers to the business disputes among relevant parties. Common Law is practiced in America, Britain and all English Speaking countries, while Civil Law is popularly applied in the rest of European or other countries. And majority of Muslim nations stand by Islamic Law.

Besides, many OBOR countries have yet to develop mature legal systems, so 
more work is required on the legal documentation to address deal and operational uncertainties and the financial risks for all the investors. Since many investments will be made in developing markets, the factor of political risk, and compliance issues such as corruption, cannot be ignored.

Cases of losses in OBOR invetment occuring in Pakistan Bharsha Dam project, Nepal's hydroelectricity power plants, Sudi Arab's Light Railway project, and in a few others such as Sri Lanka, Mynmar, and so forth are the revelations of the need for all the parties in the businesses to learn and reconcile towards their common endeavors (Rahman, 2017).

Under guidelines of New York Convention, China is planning to establish a brand new dispute settlement mechanism in order to provide legal protections including litigation, mediation and arbitration solutions for business along the Belt and Road Initiative. According to the design plan, the Supreme People's Court will set up an international commercial court in Beijing, Xi'an and Shenzhen. The court in Xi'an aims to cover commercial disputes along the land-based Silk Road Economic Belt. The court in Shenzhen will mainly deal with litigations from the oceangoing Maritime Silk Road. The headquarters will be set up in Beijing. Besides, the China Council for the Promotion of International Trade (CCPIT) is also planning to launch a new organization to prevent and resolve international disputes in accordance with the principle of "cooperating and sharing." At the end of 2017, City of Wuhan found the OBOR Arbitration Center for International Public-private Partnership Projects ( $\mathrm{Lu} \& \mathrm{He}$, 2018). In the meanwhile, the Chinese government has increased the legal diplomacy efforts in other continents, such as Malaysia, South Korea, Singapore, and certain European countries, to promote joint dispute arbitration mechanisms (Osman, 2017; Nagelmueller, 2018).

\subsection{No Strings Attached}

Non-interference as a rule for international law has been one of the major principles dictating diplomatic relationship and political order among nations, although some have found that the moral legitimacy of the regime that reigns the country can be a controversial topic. Without unequivocal specification and with actual ambiguities in reference to this rule, IGOs, FDIs, MNCs, cross nations' assistant programs have practiced such rule using various standards when it comes to contract understanding and agreement.

Chinese government has been consistently applying UN's rule of non-interference in its relations with others. One of the iconic advantages of Chinese investment contract with any of the OBOR countries is deals without strings (Boghaini \& Conway-Smith, 2013). All the projects, from contract, engineering, to goods and services thus delivered, have all gone without any political or economic strings. In effect, this business approach has been a biggest selling point to the economically underdeveloped countries, where political and economic establishments are commonly flawed and fragile (Hashim, 2017). With colonial 
oppressed experience in the past, and without reliable resources for improving existing systems in effective mode, any imposed strings upon developing countries could result in anxiety or confusion.

\section{Issues Discussion}

The OBOR initiative at this caliber of scale and missions will probably take generations to finally reach its destination. Miscalculations and unrealistic expectation will certainly hit their hurdles. Adjustment and constant improvement efforts will definitely be an indispensable part of the whole journey. Issues raised over the OBOR initiative are inevitable, however, exertion to clearly address them is also necessary for conciliatory solutions.

\subsection{Win-Win over Geopolitics}

The economic corridor between China and Pakistan is one of the most discussed issues. The core of the problem lies in this geographic connection that runs across the disputed area of Kashmir for which both India and Pakistan claim its sovereignty. China has offered India to rename the connectivity from CPEC (China Pakistan Economic Corridor) to an alternative name based on another possible route, if India joins OBOR (Dasgupta, 2017). After rounds of confrontation on land and the ocean in the past year, the most recent development between these two Asian giants has witnessed their willingness to keep dance together between the Dragon and the Elephant. When history and colonialism created the boarder problems between the two, rational leaders and cultural ties will eventually get along as no one can remain isolated for too long in the name of sovereignty (Mohan, 2017). Among all possible solutions, only peace and good neighbor seem a most realistic and plausible choice for the parties on both sides.

\subsection{Opportunities for POE}

State-owned enterprises (SOE) compete with private-owned enterprises (POE) for funding sources. So the contract opportunity is another OBOR related issue. It is a widely acknowledged fact that China's economic success has been backed by strong statism. Over the last 40 years, however, we all have experienced earth shaking transformation in this used to be "monolithic" regime. Thanks to the hybrid sources galvanizing such a change, now it is fair to say that China has taken further steps and will continuously follow the similar path towards a much freer and liberal society. One best landmark highlighting this monumental development is the permanent retreat of state-owned enterprises in the overall percentage of entrepreneurial ownership structure to only 30\% ( $\mathrm{Wu}, 2016$ ). President Xi recently promised in-depth reform while also opening more markets to foreign investors (Denyer, 2018). Therefore, we can expect more opportunities not only for private businesses from China itself, but also for the competitive businesses from all over the world in gaining various OBOR project contracts. Among all the participating MNCs, Caterpillar, GE, Heneywell, Sie- 
mens, to name just a few, can show you that business success with OBOR initiative is just a step away if POEs are competitive enough in both technology and enthusiasm. It is a matter of participation, the first step towards actuality from hypothetical assumptions.

\subsection{Transparency}

Finally, the issue of transparency has brought to everyone's attention since day one over the OBOR initiative. Basically, here is where major concerns and criticism clustered. The high standard of transparency in labor, environment, and contract bidding procedures has been set to measure OBOR policy and real performance. These are legit concerns and reasonable reactions to the problems in human rights, climate change and equal opportunity. The OBOR initiative, as it has demonstrated in above narratives and data, has been trying hard and doing well in responding to these mainstream standards.

\subsection{Policy Space for Fairer Distribution of Wealth}

To be fair, a China-led initiative will certainly need time to develop into a perfect plan that pleases everyone. As a rising economic power and a role model for underdeveloped countries, China has room to learn and grow. While this is not impossible, leaders of this grand and ambitious initiative do need some help. Help others help yourself. In fact, wealthy countries and matured states have many to offer to late comers for successful development. Together, all the parties could help with better solutions in a world that is often inflicted with chaos and confusion.

One of those solutions is tied to a proposal of policy space (Rodrik, 2007). In order to save globalization from its cheerleaders, the tentative and mutually consented opted-out arrangements from stringent liberal policies for periphery countries have proved to be feasible. Cases included MFA (Multi-Fiber Agreement), VER (Voluntary Export Restrictions), AD (Anti-dumping), and lax standards in labor, environment, "unfair trade" have actually been practiced on and off by different states over the decades since the establishment of Bretton Woods System. The rise of Western Europe, Japan, and NICs should all attribute to their taking advantage of the US' generosity. One of the key attributes of China's approach in the OBOR initiative is flexibility in cooperation with any government regardless of their nature even with Syria or Yemen; in less stringent requirements for meeting social and environmental safeguards; and in negotiating payment terms that accepts natural resources or equity (Hillman, 2018).

Tentative opted-out arrangement between China and other countries is not the ultimate approach for its socioeconomic development. Conversely, in his most recent speech in an unprecedented event-Shanghai Import Exposition, Chinese president Xi vowed to further extend the opening of Chinese markets in all categories, adhere to free trade policy, and firmly carry on commonly acknowledged rules of international system including reciprocity, multilateral cooperation, and respect of policy discretions of all partners (Xi, 2018). After all, policy space only assists to cut down the learning curves, it does not and could 
not substitute the generic rules everyone else follows to achieve their real and sustainable economic success.

On the other hand, above referred policy accommodations will definitely require understanding and empathetic concessions by developed countries. As founders of world system and wealthy brothers, developed countries' share of wisdom and wealth with not so fortunate fellows in their neighborhood is certainly substantially needed and morally appreciated.

Rule abiding maintains the stability of a functioning system; policy space for developing areas speeds up their learning process and serves one more complementary incentive to human strife for happiness. It will prove to be a cost-beneficial and effective approach in the long run. At the end of the day, shared OBOR's opportunity and responsibility will be conducive to rational distribution of wealth for all the members of the global communities. In return, the ambivalence and suspicion over the essence of OBOR may give way to a grand confidence with established rules of international regimes that is meant to be legitimate standard for retaining prosperity and peace.

\section{Authors' Notes}

Criticisms over OBOR initiative have raised a wide variety of issues about relationship between OBOR and international rules including geopolitical strategy (see remarks made by Jim Mattis, China in Shock USA Openly supports India on Opposing OBOR One Belt One Road, US Department of Defense, Hades Pictures, Oct. 5, 2017, https://www.youtube.com/watch?v=nNGO0yaIy4k; US Dept. of State, Secretary Rex Tillerson, Remarks at Town Hall-Dean Acheson Auditorium Washington, DC, December 12, 2017, https://www.state.gov/secretary/remarks/2017/12/276563.htm) national sovereignty, contract transparency, financing arrangements, environmental standards and labor standards (see India, Australia and Japan discuss OBOR concerns, The Tribune, March 27, 2019) debt traps (see Financing structure of OBOR projects will "compromise" sovereignty of participating nations, The Economic Times, May 16, 2018 https://economictimes.indiatimes.com/news/international/world-news/financin g-structure-of-obor-projects-will-compromise-sovereignty-of-participating-nati ons-us/articleshow/64190918.cms?utm_source $=$ contentofinterest\&utm_medium =text\&utm_campaign=cppst); or neocolonialism (see James, A. Millward, Is China a Colonial Power? The New York Times, May 4, 2018). The objective of this paper is to reveal the myths behind these rhetoric with our research framework, using fundamental rules of international regimes to examine the real OBOR related data. When essential rules are being used for the relevant issues analysis, not all the aspects of criticism could be included in this study. Separate research may be needed for particular issues research in the future.

\section{Conflicts of Interest}

The authors declare no conflicts of interest regarding the publication of this paper. 


\section{References}

Asia Times Staff (2018). China to Establish Court for OBOR Disputes, (Asia Times).

Atzori, G. (2016). Can China's New Silk Road Save the Greek Economy? China's Massive Project Has Enormous Implications for Greece, and Europe. The Diplomat. https://thediplomat.com/2016/01/can-chinas-new-silk-road-save-the-greek-economy

Boghaini, P., \& Conway-Smith, E. (2013). China's New President Offers Africa "No Strings" Aid. CNBC. https://www.cnbc.com/id/100593398

Bradsher, C. (2017). U.S. Firms Want In on China's Global "One Belt, One Road" Spending. The New York Times.

Camdessus, M. (2017). Why China's Belt and Road Must Be a Pathway to Sustainable Development? South China Morning Post.

Cendrowski, S. (2016). Inside China's Global Spending Spree, (Fortune); Core Sight Research, Deep Dive: One Belt One Road_Impact on Western Multinational Companies.

Chinanews (2017). How Many Jobs China Manages to Create for the World? http://www.chinanews.com/gn/2017/10-21/8357721.shtml

Dasgupta, S. (2017). China Hints It Can Rename CPEC If India Joins OBOR Initiative. The Times of India.

https://timesofindia.indiatimes.com/india/china-shows-interest-in-talking-one-belt-on e-road-plan-with-india/articleshow/61771677.cms

Denyer, S. (2018). Facing Trade War with U.S., China's Xi Renews Vow to Open Markets, Import More. The Washington Post.

Dezan Shira, \& Associates (2017). Understanding China's Free Trade Agreement along the OBOR Routes.

https://www.silkroadbriefing.com/news/2017/05/12/understanding-chinas-free-trade-a greements-along-obor-routes

Hashim, M. (2017). 21st-Cnetury Version of Silk Road. The Daily Star. https://www.thedailystar.net/opinion/no-frills/21st-century-version-silk-road-1405651

Heymann, P. (1973). The Problem of Coordination: Bargaining and Rules. Harvard Law Review, 86, 797-877. https://doi.org/10.2307/1339887

Hillman, J. (2018). China's Belt and Road Initiative: Five Years Later. CSIS (Center for Strategic and International Studies) Report.

https://www.csis.org/analysis/chinas-belt-and-road-initiative-five-years-later-0

Kanak, D. (2016). China's Belt and Road Initiative Vital to Asian Job Creation. Nikkei Asian Review.

Kant, I. (1795). Perpetual Peace. New York: Cosimo.

Lu, T., \& He, Y. (2018). Recent Developments in China's Cross-Border Dispute Resolution Under the "Belt and Road Initiative". The American Review of International Arbitration-Columbia Law School.

Lu, Y. (2017). One Belt One Road Initiative (OBOR). TDM. https://www.transnational-dispute-management.com/article.asp?key=2469

Marchetti, J., Roy, M., \& Zoratto, L. (2012). Is There Reciprocity in Preferential Trade Agreements on Services? World Trade Organization. https://www.wto.org/english/res_e/reser_e/ersd201216_e.htm

Mohan, G. (2017). Bangladesh Backs China's OBOR; Can't Remain Isolated in the Name of Sovereignty, Says Foreign Secretary. India Today.

https://www.indiatoday.in/world/story/bangladesh-backs-obor-china-cpec-initiative-sh ahidul-haque-india-1058853-2017-10-06 
Nagelmueller, M. (2018). Litigation Finance and China's Belt and Road Initiative. Litigation Finance Journal.

https://litigationfinancejournal.com/litigation-finance-chinas-belt-road-initiative

Osman, A. (2017). Transnational Dispute Management. TDM 3.

https://www.transnational-dispute-management.com/article.asp?key=2469

Paine, T. (1791). Rights of Man. New York: Oxford University Press.

People Net. List of Achievements of Belt AND Road Initiative: 2013-2016.

http://www.people.com.cn

http://en.people.cn/102775/313196/index.html

People's Daily (2017). The Theoretical Quest and Actual Achievements of One Belt One Road Construction. Beijing.

Pike, L. (2017). Explainer: Will China's New Silk Road be Green? China Dialogue. https://www.chinadialogue.net/blog/9775-Explainer-Will-China-s-new-Silk-Road-be-g reen-/en

Qiu, S., \& Zhao, L. (2017). Statistics Proof of One Belt \& One Road Achievements in Trading. People's Daily. http://www.sohu.com/a/166939734_565998

Rahman, F. (2017). The Setbacks and Achievements of One Belt One Road. Mango News. http://www.themangonews.com/international/setbacks-achievements-one-belt-one-road

Rodrik, D. (2007). How to Save Globalization from Its Cheerleaders. Journal of International Trade and Diplomacy, 1, 1-33. https://doi.org/10.2139/ssrn.1019015

Schumpeter, J. (1955). Imperialism and Social Classes (p. 68). New York: Meridian.

Shepard, W. (2017). These 8 Companies Are Bringing the "New Silk Road" to Life. Forbes.

The Sirius Report (2018). Caterpillar Takes Advantage of the OBOR Initiative inside China. https://thesiriusreport.com/economics/caterpillar-obor-initiative-china

Trentmann, N. (2017). Western Firms Bet Big on China's Billion-Dollar Infrastructure Project-Honeywell, GE and Caterpillar Are Set to Benefit from International "One Belt, One Road" Effort. Wall Street Journal.

https://www.wsj.com/articles/western-firms-bet-big-on-chinas-billion-dollar-infrastruc ture-project-1494790205

Villafuerte, J., Corong, E., \& Zhuang, J. (2016). The One Belt, One Road Initiative: Impact on Trade and Growth. Hong Kong: HKTDC.

https://www.gtap.agecon.purdue.edu/resources/download/8280.pdf

Wang, Y. L. (2017). The Investment Messages for OBOR-1.2 Trillion USD in 10 Years. Jiemian. http://www.jiemian.com/article/1823639.html

World Trade Organization. Understanding the WTO: Basics. Geneva. https://www.wto.org/english/thewto_e/whatis_e/tif_e/fact2_e.htm

Wu, J. (2016). Despite China Favoring State-Owned Enterprises, Its Private Companies are More Innovative and Productive. Washington DC: ITIF, Information Technology \& Innovation Foundation.

https://itif.org/publications/2016/11/29/despite-china-favoring-state-owned-enterprise s-its-private-companies-are

Wu, Y. (2017). China's One Belt One Road Initiative Will Need Africa's Support to Work. Quartz Africa.

https://qz.com/993861/obor-chinas-one-belt-one-road-initiative-needs-africas-support

Xi, Jinping's Keynote Speech in the Shanghai Import Expo. Xinhua Net, Nov. 5, 2018. http://www.xinhuanet.com/politics/leaders/2018-11/05/c_1123664692.htm

Yamei (2017). Joint communiqué of Leaders Roundtable of Belt and Road Forum. Xinhua 
Agency.

Zhao, J. P., \& Luo, Y. Z. (2017). The Theoretical Probe and Actual Achievements of One Belt One Road Construction. China Daily.

http://www.chinanews.com/ll/2017/05-11/8220889.shtml 